ZBigniew GrZYMAŁA

Szkoła Główna Handlowa, Warszawa, Polska

\title{
Innowacje na rynku sektora komunalnego w Polsce
}

\section{Innovations on the Municipal Market in Poland}

\begin{abstract}
Streszczenie: W gospodarce komunalnej podobnie jak w innych sektorach gospodarczych mamy do czynienia z działaniami innowacyjnymi między innymi na poziomie produktowym, procesowym i organizacyjnym. Liderami w tym zakresie w Europie są przede wszystkim kraje skandynawskie oraz Niemcy i Szwajcaria. Innowacje produktowe znane od dłuższego czasu i procesowe dotyczą między innymi: pozyskiwania energii cieplnej i elektrycznej z paneli słonecznych i spalania odpadów komunalnych, wykorzystywania odpadów stałych i płynnych (ścieków) do produkcji energii dokonywane w tzw. kogeneracji branżach: odpadowej, cieplnej i wytwarzania energii elektrycznej.

Innowacją organizacyjną w gospodarce komunalnej jest tworzenie komunalnych grup kapitałowych, dzięki którym można przez efekt skali obniżać koszty świadczenia usług komunalnych oraz gromadzić środki na badania i wdrożenia innowacyjne. Najbardziej zaawansowane w tym zakresie są również kraje zachodnie: Niemcy, Francja, kraje skandynawskie.

Polska pomimo wielu inicjatyw proinnowacyjnych, w tym wykorzystania środków pomocowych z UE, aktywności ośrodków akademickich czy inicjatyw samorządów terytorialnych, między innymi Stalowej Woli, jest postrzegana jako kraj poza głównym nurtem innowacyjności. Średnio na milion mieszkańców notuje się 20 patentów rocznie wobec prawie $1500 \mathrm{w}$ tzw. Wielkiej Szwajcarii. Propagacja wszystkich pozytywnych inicjatyw w zakresie innowacyjności przy wsparciu jeszcze niesprzedanych przedsiębiorstw branż komunalnych jest jedną z możliwości poprawy poziomu innowacyjności w Polsce. Dodatkowym rozwiązaniem byłoby tworzenie spółek europejskich łączących kapitał polski i zagraniczny, ale na tych samych zasadach dla obu typów kapitału.
\end{abstract}

\footnotetext{
Abstract: The municipal sector, as other sectors of the economy, has to do with innovation activities at least on the level of product types, process and organization. Leaders in this field in Europe are primarily the Scandinavian countries, Germany and Switzerland. Product innovations, which have been known for a long time, and process innovations regard the following: thermal energy and electricity from solar panels and waste incineration, the use of solid and liquid waste (sewage) for energy production is carried out in the so-called cogeneration sectors: waste, heat and electricity generation.

Despite many pro-innovation initiatives, including the use of EU aid, academic activities and initiatives of local governments including Steel Will, Poland is generally seen as outside the mainstream of innovation.
} 
Propagation of all the positive initiatives in innovation with the support of companies not sold yet of municipal sectors is one of the opportunities to improve the level of innovation in Poland.

Słowa kluczowe: bariery; gospodarka komunalna; grupy kapitałowe; innowacje

Key words: barriers; capital groups; innovation; municipal economy

\section{WSTĘP}

Sektor usług komunalnych w Polsce nadal jest postrzegany przez większość decydentów gospodarczych jako mało innowacyjny, którego zakres oddziaływania ogranicza się do lokalnego obszaru. W definicjach określających gospodarkę komunalną zwrócono uwagę na konieczność dostarczania usług komunalnych w sposób niezawodny - zarówno w czasie, jak i przestrzeni - w skali społecznej. Przerwanie dostawy tych dóbr lub dostarczanie ich w sposób niewłaściwy może wywołać poważne konsekwencje w życiu społecznym od epidemii do paraliżu komunikacji i całego życia gospodarczego włącznie. Dobra komunalne charakteryzują się tym, że trudno je w zasadzie magazynować (por. Grzymała, 2010: 42). Te cechy utrwaliły w Polsce dosyć zachowawcze podejście do sektora komunalnego. Świadczenie usług komunalnych wydaje się stabilnym i niepodatnym na zmiany działaniem. Na przykład co można w opinii sporej części menedżmentu samorządowego zmienić w dostawie wody czy odprowadzaniu ścieków albo w gospodarce odpadami czy elektroenergetyce? Technika dostawy tych usług jest znana. Może ulegać jedynie pewnym ulepszeniom bez znaczących modyfikacji. Stosunkowo słabą dynamikę w zakresie innowacyjności w Polsce podkreślają także - w branży biotechnologii S. Dorocki i J.P. Jastrzębski (por. Dorocki, Jastrzębski, 2012).

Rozwiązania przyjęte na Zachodzie w sektorze komunalnym od wielu lat pokazują jednak możliwość dokonywania wielu innowacji w branżach uznawanych w Polsce za niezmienne lub niewarte uwagi. Celem artykułu jest przegląd wybranych innowacji w gospodarce komunalnej zapoczątkowanych w krajach Europy Zachodniej oraz określenie przyczyn niskiej innowacyjności w Polsce. Autor będzie proponował rozwiązania sprzyjające jego zdaniem poprawie innowacyjności w tym zakresie w naszym kraju.

\section{PoJĘCIE INNOWACYJNOŚCI}

Zgodnie z Podręcznikiem Oslo (2008: 48-55), przez innowację należy rozumieć wprowadzenie do praktyki w gospodarce nowego lub znacząco ulepszonego rozwiązania w odniesieniu do produktu (towaru lub usługi), procesu, marketingu lub organizacji.

Zgodnie z powyższą definicją można rozróżnić następujące typy innowacji:

- produktową, oznaczającą wprowadzenie na rynek przez dane przedsiębiorstwo nowego towaru lub usługi, lub znaczące ulepszenie oferowanych uprzednio towarów i usług w odniesieniu do ich charakterystyk lub przeznaczenia, 
- procesową, oznaczającą wprowadzenie do praktyki w przedsiębiorstwie nowych lub znacząco ulepszonych metod produkcji lub dostawy,

- marketingową, oznaczającą zastosowanie nowej metody marketingowej obejmującej znaczące zmiany w wyglądzie produktu, jego opakowaniu, pozycjonowaniu, promocji, polityce cenowej lub modelu biznesowym, wynikającej z nowej strategii marketingowej przedsiębiorstwa,

- organizacyjną, polegająca na zastosowaniu w przedsiębiorstwie nowej metody organizacji jego działalności biznesowej, nowej organizacji miejsc pracy lub relacji zewnętrznych.

Zgodnie z zapisami Podręcznika Oslo „czynności rutynowe związane z oprogramowaniem, niepociągające za sobą postępu naukowego czy technicznego ani wyeliminowania niepewności o charakterze technicznym, nie powinny być zaliczane do B+R".

Przykłady czynności, które nie są pracami $\mathrm{B}+\mathrm{R}$ :

- tworzenie aplikacji biznesowych i systemów informatycznych na podstawie znanych metod $\mathrm{i}$ istniejących narzędzi informatycznych,

- obsługa istniejących systemów,

- konwersja oraz/lub tłumaczenie języków komputerowych,

- dodawanie funkcjonalności dla użytkownika w programach użytkowych,

- usuwanie błędów z systemów (debugging),

- adaptacja istniejącego oprogramowania,

- przygotowywanie dokumentacji dla użytkownika (Przewodnik po kryteriach, 2012).

Na rycinie 1 zaprezentowano wielkość innowacji na milion mieszkańców, w wybranych regionach Europy i państwach.

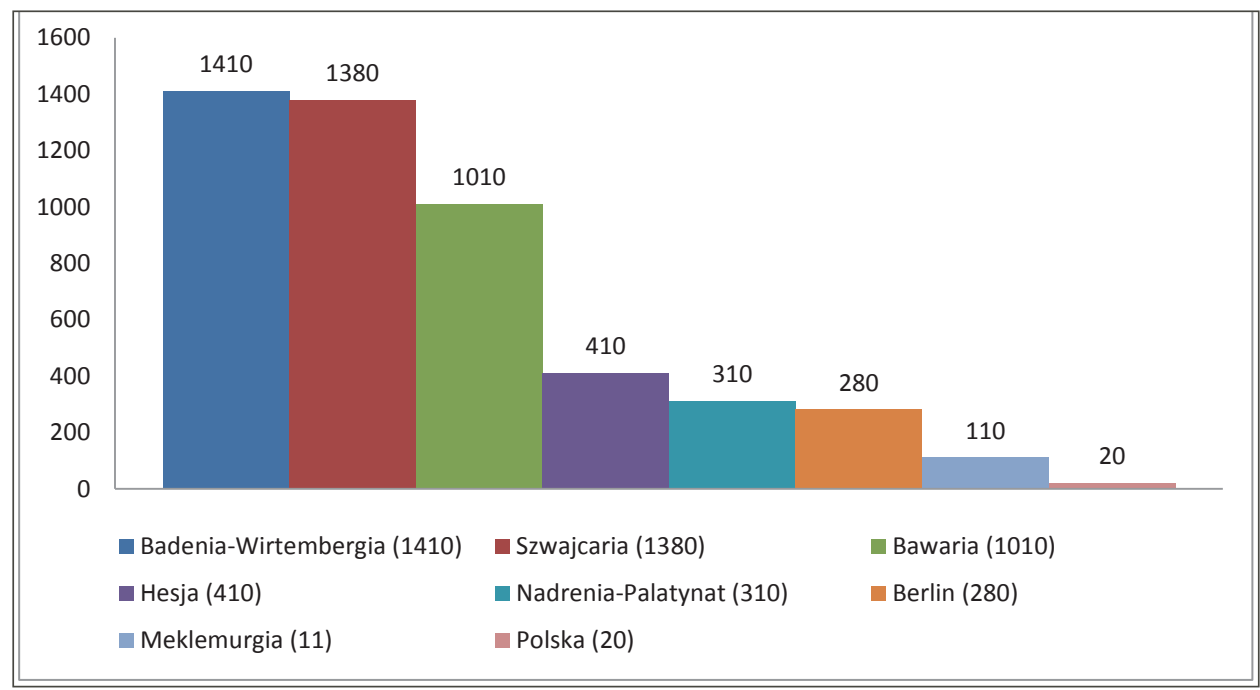

Ryc. 1. Liczba patentów na milion mieszkańców w wybranych regionach i państwach Źródło: Stach, 2012 
Interpretując dane z ryciny 1, Polskę można zakwalifikować jako kraj o niskim poziomie innowacyjności, a nawet wykluczony z głównego nurtu innowacyjnego. W branżach uznawanych za komunalne w Europie wdrożono przynajmniej innowacje typu produktowego, procesowego i organizacyjnego. Za najbardziej nowatorską branżę uznaje się elektroenergetykę i gospodarkę odpadami. W tych branżach powstały innowacje produktowe i procesowe również w ramach tzw. kogeneracji tych branż. Z kolei innowacja organizacyjna, w Europie to przede wszystkim istniejące i poszerzające swój obszar działalności komunalne grupy kapitałowe przekraczające swym zasięgiem obszar jednego kraju.

\section{PRZYKŁADY INNOWACJI W BRANŻACH KOMUNALNYCH}

Powszechnie znanymi innowacjami są innowacje w branży elektroenergetycznej. Polegają na wytwarzaniu energii między innymi z ogniw fotowoltaicznych. Na rycinie 2 przedstawiono jeden z bardziej innowacyjnych regionów w Europie między innymi w zakresie fotowoltaiki, tzw. Wielką Szwajcarię. W regionie tym średnio notuje się 1410 wynalazków na milion mieszkańców (Stach, 2012).

Farma w Bawarii na przykład zajmuje powierzchnię $4000 \mathrm{~m}^{2}$ i produkuje 410 tys. $\mathrm{kWh}$ energii elektrycznej. Zainwestowany kapitał wynosił 600 tys. euro. Dochód netto z tej inwestycji to 81 tys. euro, (14)\% rocznie. Dochód ten odpowiadał zyskowi gospodarstwa 1000 ha hodującego 5 tys. krów (Stach, 2012).

Energia słoneczna jest wbrew twierdzeniom lobby paliwowo-energetyczno-samochodowo-politycznego dostępna w nadmiarze od Afryki do Sztokholmu. Pokazują to jednoznacznie wyniki następujących pomiarów (Stach, 2012):

- strefa równikowo-zwrotnikowa (Sahara)

$2400 \mathrm{~W} / \mathrm{m}^{2}$

- Rzym $1800 \mathrm{~W} / \mathrm{m}^{2}$

- Stuttgart $50^{\circ} \mathrm{N}$ (Szerokości geogr. północnej) $1050 \mathrm{~W} / \mathrm{m}^{2}$

- Stalowa Wola $50^{\circ} \mathrm{N}$ $1050 \mathrm{~W} / \mathrm{m}^{2}$

- Sztokholm $60^{\circ} \mathrm{N}$ $850 \mathrm{~W} / \mathrm{m}^{2}$ 


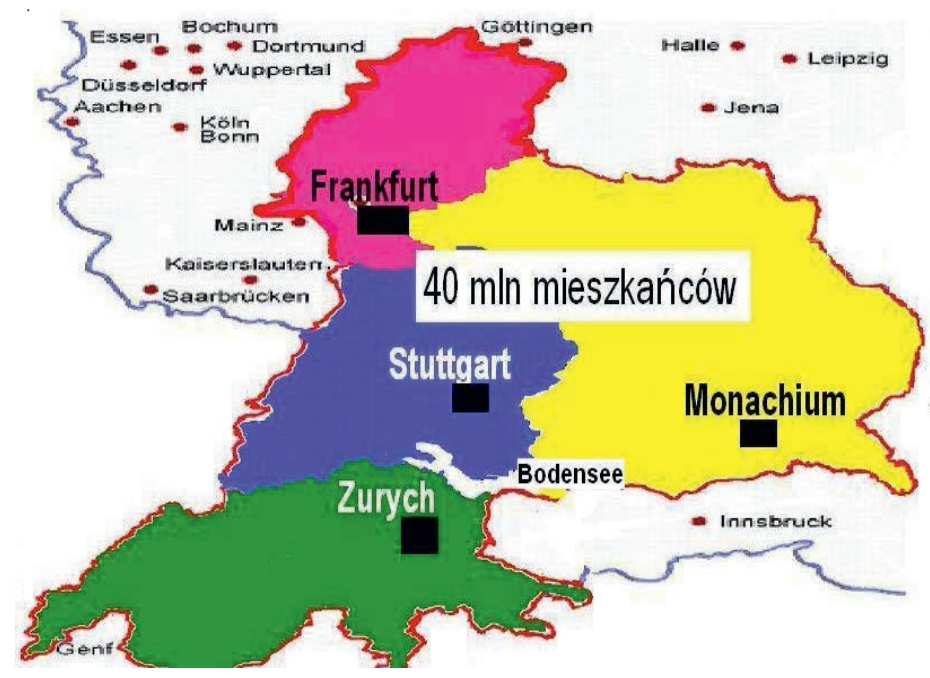

Ryc. 2. Obszar tzw. Wielkiej Szwajcarii

Źródło: Stach, 2012

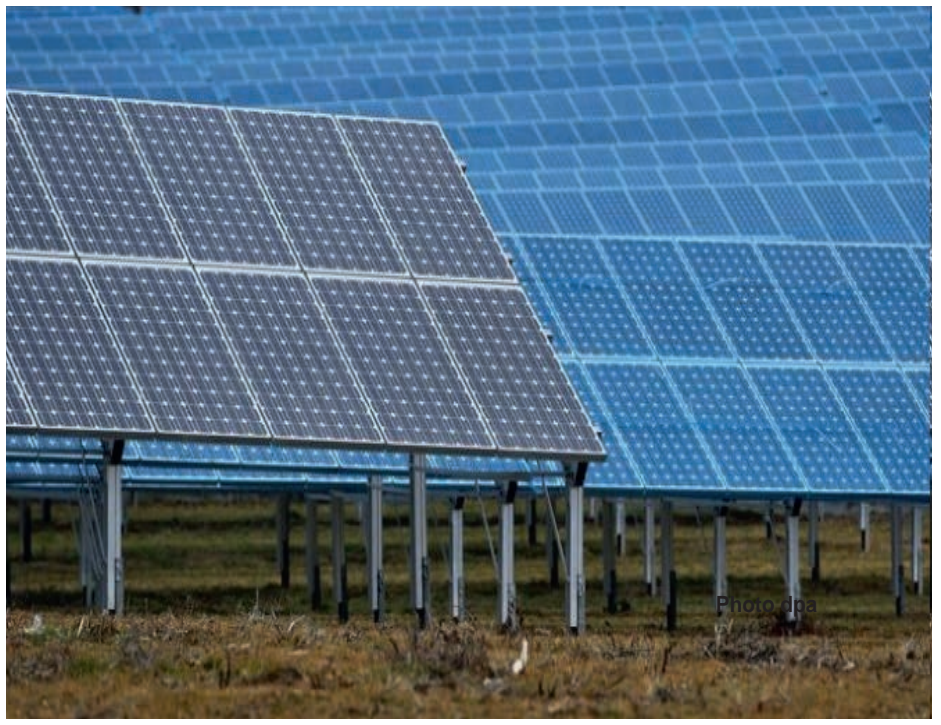

Ryc. 3. Farma fotowoltaiczna w Bawarii

Źródło: Stach, 2012

Na rycinie 3 z kolei zaprezentowano farmę fotowoltaiczną w Bawarii produkującą energię elektryczną.

W branży wodociągowo-kanalizacyjnej innowacje zapoczątkowały kraje skandynawskie, głównie Szwecja. Dotyczyły przerobu ścieków w oczyszczalni. Ciepło z tych ścieków 
jest wykorzystywane do produkcji energii elektrycznej i biogazu. Na kolejnej rycinie (ryc. 4) zaprezentowano możliwości wytwarzania energii przez taką oczyszczalnię w Szwecji.

Kolejnym przykładem innowacji typu produktowego i procesowego jest uzyskiwanie energii cieplnej i elektrycznej z odpadów komunalnych. Na rycinach 5 i 6 ukazano przykłady takich spalarni w Szwecji.

\section{Szwedzkie oczyszczalnie ścieków}

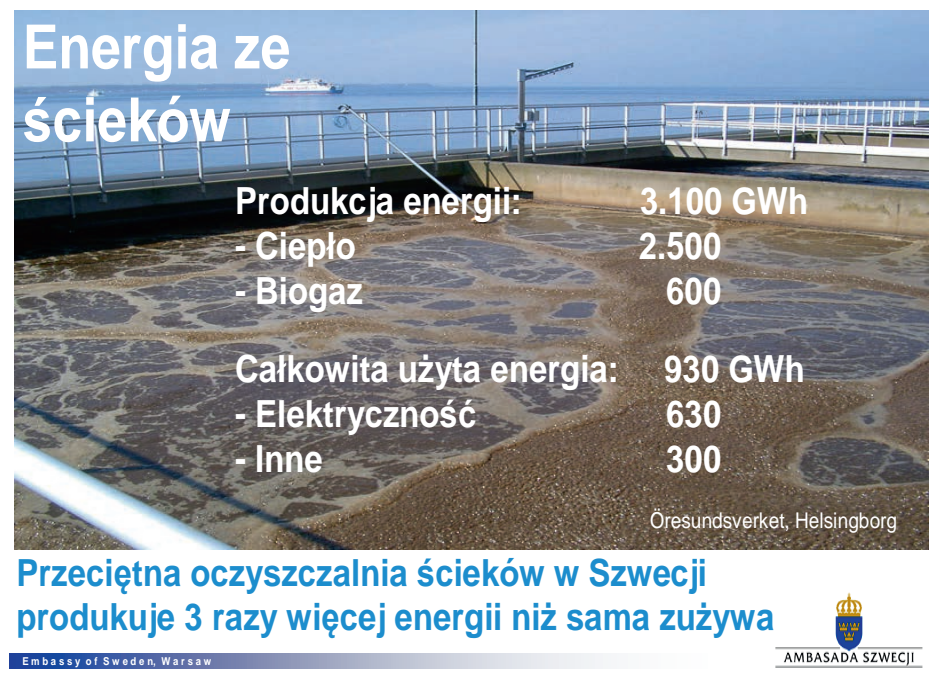

Ryc. 4. Możliwości energetyczne oczyszczalni ścieków w Szwecji

Źródło: Haglund, 2011

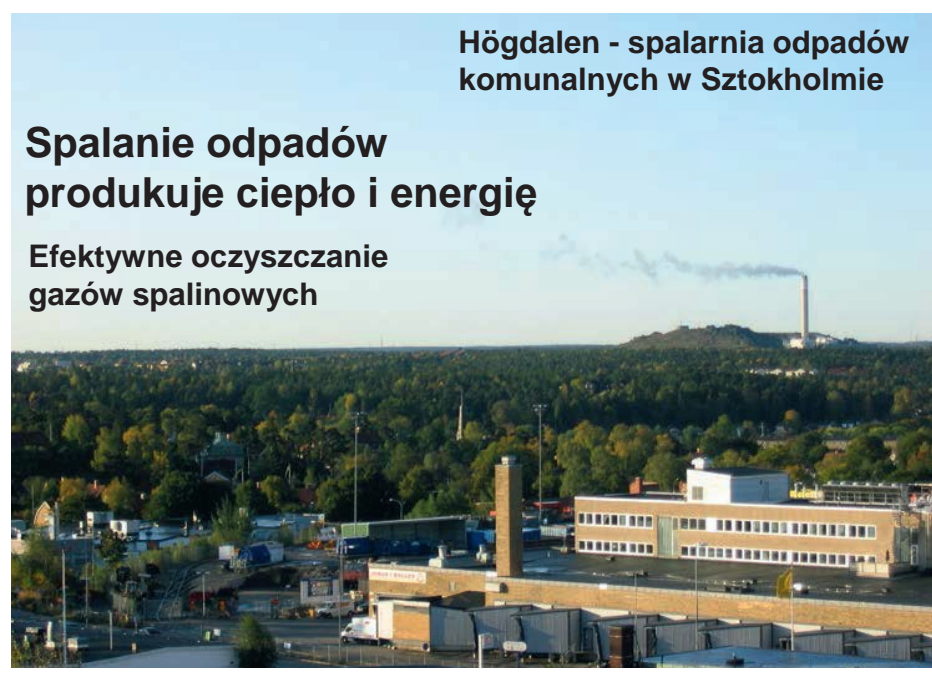

Ryc. 5. Spalarnia odpadów komunalnych w Sztokholmie

Źródło: Haglund, 2011 


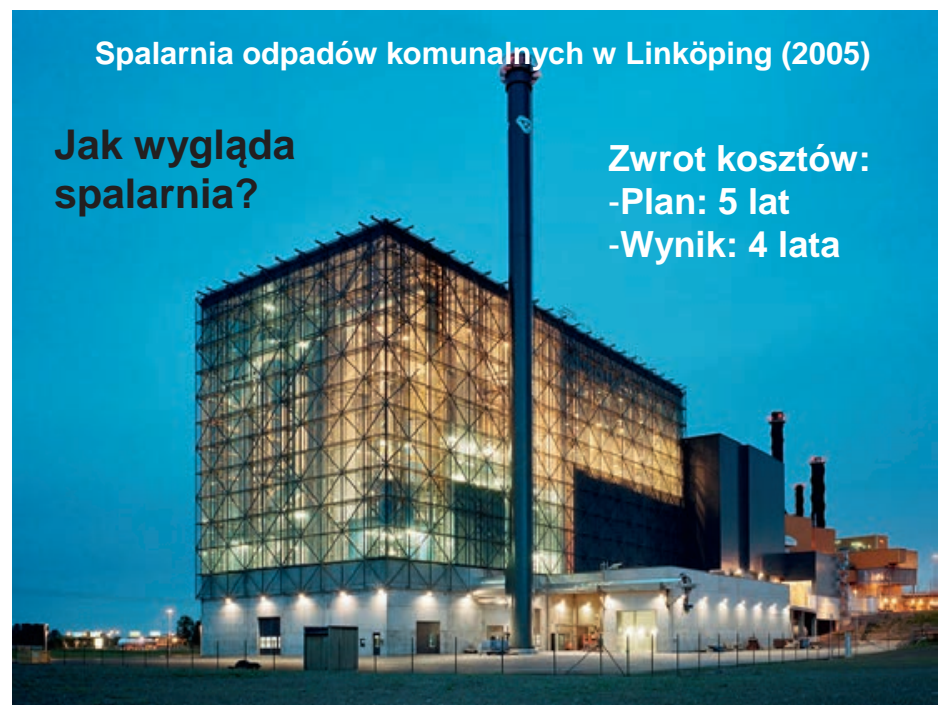

Ryc. 6. Spalarnia odpadów w Linköping

Źródło: Haglund, 2011

\section{Biogaz z odpadów komunalnych}

W Szwecji nie ma sieci gazowej i dlatego biometan jest używany do napędu pojazdów komunalnych.

W miastach Borás, Helsingborg, Linköping i Västerảs (po około 100000 mieszkańców) wszystkie autobusy i śmieciarki napędzane są tak wytworzonym biogazem.
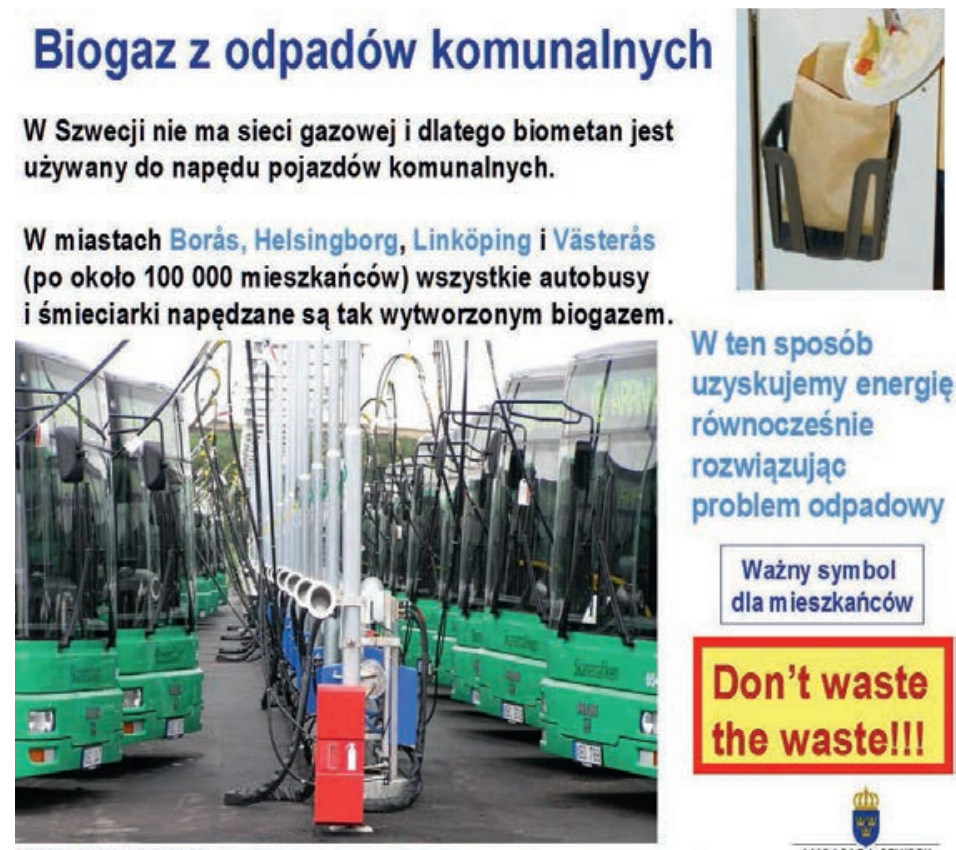

W ten sposób uzyskujemy energię równocześnie rozwiązując problem odpadowy

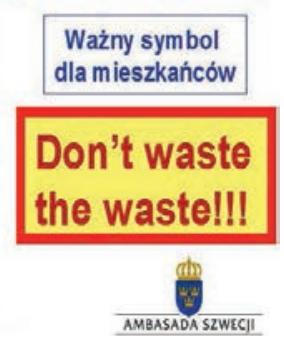

Ryc. 7. Wykorzystanie biogazu do napędzania taboru komunikacji miejskiej w Szwecji Źródło: Haglund, 2011 
Między innymi w Szwecji na szeroką skalę wykorzystuje się biogaz uzyskany z odpadów stałych i ścieków. Na rycinie 7 przedstawiono wykorzystanie biogazu w komunikacji miejskiej.

Przykładem innowacji organizacyjnej są międzynarodowe komunalne grupy kapitałowe. Jedną z takich grup jest Veolia tworząca grupę kapitałową również w Polsce. Veolia w Polsce obejmuje kompleks branż komunalnych, w jej skład wchodzą: Veolia Transport zajmująca rynek przewozów pasażerskich, Veolia Energy, której częścią składową jest Dalkia Polska S.A. zaopatrująca w energię cieplną i elektryczną od 2005 r. Łódź i okoliczne miasta oraz od 2002 r. Poznań i poznański rynek regionalny. Dalkia posiada większościowe pakiety akcji pozwalające kontrolować jej rynki, na których prowadzi swoją działalność. Oprócz dostawy energii cieplnej czy elektrycznej produkuje również paliwa dla elektrociepłowni w swoich spółkach córkach. W skład Veolii wchodzi również Veolia Environment, zajmująca się gospodarką odpadami, Veolia Water, która w Polsce posiada pakiet większościowy w Przedsiębiorstwie Wodociągów i Kanalizacji w Tarnowskich Górach.

Inną firmą funkcjonującą za pośrednictwem infrastruktury sieciowej i przekraczającą obszar rynku lokalnego jest fiński koncern Fortum. Na rynku polskim działa również szwedzki koncern energetyczny Vattenfall AB. W skład grupy działającej na terenie naszego kraju wchodzą: Vattenfall Heat Poland S.A. (dawne elektrociepłownie warszawskie), Vattenfall Distribution Poland (dawny Górnośląski Zakład Elektroenergetyczny) i Vattenfall Sales Poland (dawne GZE Kontakt). Vattenfall Heat Poland S.A. jest największym producentem ciepła spośród 23 spółek, elektrociepłowni zawodowych działających na rynku energetycznym w Polsce (por. Grzymała, 2010: 217-218). Do polskiej branży energetycznej, w tym cieplnej, weszły również: francuski koncern EDF - do Krakowa, Wrocławia, Rybnika, Zielonej Góry, Gdańska, Tarnobrzega; czeski CEZ, który w zakresie energii cieplnej objął przede wszystkim udziały elektrociepłowni Elcho sp. z o.o. w Chorzowie; czy francusko-hiszpański SNET - między innymi w Białymstoku. Wymienione firmy przekraczają obszar rynku lokalnego i działają na rynku regionalnym, a niekiedy nawet w różnych punktach kraju. W branży gospodarki odpadami takimi grupami są: Temondis czy Sita. Grupy te, wykorzystując efekt skali, obniżają koszty jednostkowe. Jednocześnie dzięki doświadczeniu globalnemu podwyższają jakość świadczonych usług. Grupy te są także w stanie finansować działania typu $\mathrm{B}+\mathrm{R}$.

\section{PRZYCZYNY NISKIEJ INNOWACYJNOŚCI W POLSCE}

Na relatywnie niską innowacyjność w naszym kraju miał wpływ system ekonomiczno-społeczny, dominujący do 1989 r. System ten pomimo rejestracji nowych patentów do roku 1989 nie był w stanie skutecznie promować nowych innowacji, nie tylko zresztą w gospodarce komunalnej. Jako negatywny przykład działań antyinnowacyjnych w tamtym okresie może posłużyć historia komandora Antoniego Kamusińskiego, który jako pierwszy człowiek na świecie dowiódł matematycznie pomyłkę Alberta Einsteina dotyczącą stałej 
prędkości światła. Jego obliczenia dokonane w latach 70. XX w. nie zostały nawet opublikowane. Świadczy to wyraźnie o braku otwartości na rewolucyjne wynalazki tworzone w teorii i praktyce w Polsce (Wojnowski, 2005).

Po przyjęciu nowego systemu ekonomiczno-społecznego czynnikami hamującymi polską innowacyjność były między innymi:

1. Wyprzedaż po 1989 r. globalnych polskich przedsiębiorstw, co zamknęło proste źródła finansowania krajowych innowacji.

2. Konsekwentne i systematyczne, jakby celowe działania zmierzające do pozbycia się rentownych przedsiębiorstw komunalnych (tzw. dojnych krów), które mogłyby finansować innowacje w branżach komunalnych i stać się zalążkiem polskich komunalnych grup kapitałowych. Przykłady znane autorowi osobiście to sprzedaż lub próba sprzedaży takich przedsiębiorstw w Warszawie (2013 r.) i Łodzi (lata 2011-2012).

3. Relatywnie słabsze finansowanie projektów innowacyjnych przez system bankowy w Polsce, szczególnie w odniesieniu do przedsiębiorców bez tzw. historii.

4. System edukacji, począwszy od szkoły podstawowej, który słabo promuje i wynagradza za pomysły i działania innowacyjne.

5. Relatywnie nisko oceniana polska polityka gospodarcza, jak i wiedza oraz działania polityków w zakresie innowacji.

W Polsce można zauważyć również pozytywne zjawiska związane z działaniami innowacyjnymi. Na przykład w Stalowej Woli tworzy się zalążki polskiej komunalnej grupy kapitałowej. Na terenie całego raju powstają związki i porozumienia komunalne, które taki charakter przybierają. Źródłem zachęt proinnowacyjnych są również niektóre polskie ośrodki akademickie, w tym Szkoła Główna Handlowa. Na uczelni tej realizowany jest projekt dotyczący integracji kapitałowej dla innowacyjności. W ramach środków publicznych, w tym z Unii Europejskiej, prowadzi się konkursy na badania i wdrożenia innowacyjne, choćby z Programu Operacyjnego Infrastruktura i Środowisko. Ważne, aby te wszystkie inicjatywy nie zostały zahamowane przez może nieuświadomione działania polityków szczebla lokalnego i centralnego. Propagacja wszystkich pozytywnych inicjatyw przy wsparciu jeszcze niesprzedanych przedsiębiorstw branż komunalnych jest jedną z możliwości poprawy poziomu innowacyjności w Polsce. Dodatkowym rozwiązaniem byłoby tworzenie spółek europejskich, które łączyłyby kapitał polski i zagraniczny, ale na tych samych zasadach dla obu typów kapitału (por. także Maśloch, 2012).

\section{Podsumowanie}

W gospodarce komunalnej, podobnie jak w innych sektorach gospodarczych, mamy do czynienia z działaniami innowacyjnymi między innymi na poziomie produktowym, procesowym i organizacyjnym. Liderami w tym zakresie w Europie są przede wszystkim kraje skandynawskie oraz Niemcy i Szwajcaria. 
Innowacją organizacyjną w gospodarce komunalnej jest tworzenie komunalnych grup kapitałowych, dzięki którym można przez efekt skali obniżać koszty świadczenia usług komunalnych oraz gromadzić środki na badania i wdrożenia innowacyjne. Najbardziej zaawansowane w tym zakresie są również kraje zachodnie: Niemcy, Francja, kraje skandynawskie.

Polska pomimo wielu inicjatyw proinnowacyjnych, w tym wykorzystania środków pomocowych z UE, aktywności ośrodków akademickich czy inicjatyw samorządów terytorialnych, między innymi w Stalowej Woli, jest postrzegana jako kraj poza głównym nurtem innowacyjności. Średnio na milion mieszkańców notuje się 20 patentów rocznie wobec prawie 1500 w tzw. Wielkiej Szwajcarii.

Propagacja pozytywnych inicjatyw w zakresie innowacyjności przy wsparciu jeszcze istniejących polskich przedsiębiorstw branż komunalnych jest jedną z możliwości poprawy poziomu innowacyjności w Polsce. Dodatkowym rozwiązaniem byłoby tworzenie spółek europejskich, które łączyłyby kapitał polski i zagraniczny, ale na tych samych zasadach dla obu typów kapitału.

\section{Literatura}

Dorocki, S., Jastrzębski, J.P. (2012). Regionalne zróżnicowanie rozwoju biotechnologii w Europie. Prace Komisji Geografii Przemystu Polskiego Towarzystwa Geograficznego, 20.

Grzymała, Z. (2010). Restrukturyzacja sektora komunalnego w Polsce. Aspekty organizacyjno-prawne i ekonomiczne. Warszawa: Oficyna Wydawnicza SGH.

Haglund, G. (2011). Ekologicznie efektywna Szwecja. Warszawa: Materiały ambasady Szwecji.

Maśloch, G. (2012). Wybrane problemy realizacji inwestycji w jednostkach samorządu terytorialnego przy udziale środków pomocowych Unii Europejskiej. W: R. Brol (red.), Gospodarka lokalna i regionalna w teorii i praktyce. Wrocław: Uniwersytet Ekonomiczny we Wrocławiu.

Podręcznik Oslo. Pomiar działalności naukowej i technicznej. Zasady gromadzenia i interpretacji danych dotyczacych innowacji. (2008). Warszawa: OECD, Eurostat.

Przewodnik po kryteriach dla projektów finansowanych w ramach Działań 1.4.-4.1., finansowanych tylko w ramach Działania 1.4. (2012, 20 grudnia). Pozyskano z http://www.nauka.gov. pl/fileadmin/user_upload/Finansowanie/fundusze_europejskie/PO_IG/Dokumenty/20110224 Przewodnik_po_kryteriach_-1.4_PO_IG.pdf

Stach, A. (2012). Europejski Klub, European Academy of Technology \& Management Schloss Oedheim, D-74229 Oedheim. Stalowa Wola - materiały konferencyjne.

Wojnowski, W. (2005). Przedmowa. Zeszyty Naukowe Akademii Marynarki Wojennej, XLVI, 4 (163). 
Zbigniew Grzymała, prof. SGH dr hab., Szkoła Główna Handlowa, Katedra Ekonomiki i Finansów Samorządu Terytorialnego.

Kierownik Katedry Ekonomiki i Finansów Samorządu Terytorialnego w Kolegium Zarządzania i Finansów Szkoły Głównej Handlowej. Główne pola badawcze: restrukturyzacja przedsiębiorstw komunalnych, analiza ekonomiczno-finansowa przedsiębiorstw infrastrukturalnych, odnawialne źródła energii, strategie rozwoju jednostek samorządu terytorialnego, gospodarka przestrzenna, zarządzanie nieruchomościami, finansowanie rozwoju innowacji w Polsce. Pełnione funkcje: ekspert PARP, KIGO, KIG.

Zbigniew Grzymala, head of the Department of Economics and Finance, Local Government at the College of Management and Finance, Warsaw School of Economics. Main research areas: corporate restructuring municipal economic and financial analysis of infrastructure companies, renewable energy sources, development strategies of local governments, land management, property management, financing innovation in Poland. Positions held: expertof Polish Agency for Enterprise Development, National Chamber of Waste management, National Chamber of Commerce.

adres/address: Szkoła Główna Handlowa, Katedra Ekonomiki i Finansów Samorządu Terytorialnego Al. Niepodległości 162, 02-554 Warszawa, Polska

e-mail: zbigniew.grzymala@sgh.waw.pl 